\title{
New localities, range extension, natural history, and conservation status of Nymphargus mixomaculatus (Guayasamin, Lehr, Rodriguez \& Aguilar, 2006)
}

\author{
Pablo Javier Venegas ${ }^{1,2^{*}}$, Luis Alberto García-Ayachi ${ }^{1,2}$ \\ 1 Instituto Peruano de Herpetología, Lima, Peru • PJV: sancarranca@yahoo.es (D) https://orcid.org/0000-0002-6501-4492 \\ - LAGA: lgarciaayachi@gmail.com (D) https://orcid.org/0000-0002-3529-1261 \\ 2 División de Herpetología, Centro de Ornitología y Biodiversidad, Lima, Peru \\ * Corresponding author
}

\begin{abstract}
We provide information on the distribution, natural history, and conservation status of Nymphargus mixomaculatus (Guayasamin, Lehr, Rodriguez \& Aguilar, 2006), a species from central Peru which is currently considered as Critically Endangered. We report four new localities and extend the altitudinal distribution by $430 \mathrm{~m}$ and the geographic range by $513 \mathrm{~km}$ in a straight line northwest of the previous, only known locality. Furthermore, based on our new data and following the criteria and categories of the International Union for Conservation of Nature, we suggest that $N$. mixomaculatus should be recategorized as Vulnerable.
\end{abstract}

\section{Key words}

Centrolenidae, glass frog, habitat lost, IUCN Red List, montane forest, Peru, protected areas

Academic editor: Daniel Passos | Received 7 July 2020 | Accepted 25 January 2021 | Published 8 March 2021

Citation: Venegas PJ, García-Ayachi LA (2021) New localities, range extension, natural history, and conservation status of Nymphargus mixomaculatus (Guayasamin, Lehr, Rodriguez \& Aguilar, 2006). Check List 17 (2): 407-414. https://doi.org/10.15560/17.2.407

\section{Introduction}

The Neotropical frogs of the family Centrolenidae, commonly known as glassfrogs, are a monophyletic taxon that contains about 150 species classified into 12 genera (Guayasamin et al. 2009, 2020). Among the 8,263 species of anurans in the world (AmphibiaWeb 2020), glassfrogs stand out by their unique morphology and behavior, which include forward-directed eyes, green dorsum in most species, completely or partially translucent venter, and out-of-water deposition of eggs along streams (Guayasamin et al. 2009, 2020). In Peru, we know of the presence of 38 species of glassfrogs from the nine genera: Centrolene Jiménez de la Espada, 1872, Chimerella
Guayasamin, Castroviejo-Fisher, Trueb, Ayarzagüena, Rada \& Vilà, 2009, Cochranella Taylor, 1951, Espadarana Guayasamin, Castroviejo-Fisher, Trueb, Ayarzagüena, Rada \& Vilà, 2009, Hyalinobathrachium RuizCarranza \& Lynch, 1991, Nymphargus Cisneros-Heredia \& McDiarmid, 2007, Rulyrana Guayasamin, CastroviejoFisher, Trueb, Ayarzagüena, Rada \& Vilà, 2009, Teratohyla Taylor, 1951, and Vitreorana Guayasamin, Castroviejo-Fisher, Trueb, Ayarzagüena, Rada \& Vilà, 2009 (AmphibiaWeb 2020).

The Critically Endangered Nymphargus mixomaculatus (Guayasamin, Lehr, Rodriguez \& Aguilar, 2006) is 
a poorly known species of glassfrog endemic from Peru, currently known only from its type locality in the Cordillera del Carpish in central Peru, Huánuco Department, at elevations from 2,625 to 2,750 $\mathrm{m}$ a.s.1. (Guayasamin et al. 2006; IUCN SSC Amphibian Specialist Group 2018). According to the International Union for the Conservation of Nature (IUCN SSC Amphibian Specialist Group 2018), the species was assessed as Critically Endangered under criteria B1ab(iii), as extent of occurrence (EOO) is estimated as $10 \mathrm{~km}^{2}$, the number of locations is one, and there is a continuing decline in the area and quality of its habitat.

During herpetological inventories carried out during the last two decades in the Andes of northern Peru (Amazonas and San Martín departments), we gathered new data about the distribution and natural history of $N$. mixomaculatus. Here, we report four new localities and extend the distribution of this species, comment on some aspect about its natural history, and suggest an update to its IUCN Red List conservation status.

\section{Methods}

Specimens collected for this study are covered by the following research permits issued by the Ministerio de Agricultura and Servicio Nacional de Áreas Naturales y Protegidas por el Estado: 0581-2011-AG-DGFFSDGEFFS， 295-2017-SERFOR/DGGSPFFS， 299-2017 SERFOR/DGGSPFFS， $N^{\circ}$ 004-2019-SERNANP-JEF, and 067-2019-MINAGRI-SERFOR-DGGSPFFS. We collected voucher specimens of $N$. mixomaculatus, and euthanized them with a cutaneous dose of benzocaine $7.5 \%$. The specimens were fixed over $24 \mathrm{~h}$ in $10 \%$ formalin, stored in $70 \%$ ethanol, and finally deposited in the herpetological collection of the Centro de Ornitología y Biodiversidad (CORBIDI), Lima, Peru. Sex of specimens was determined in the field when individuals were heard calling or by dissecting the gonads in the laboratory.

Conservation status was assessed using the IUCN criteria (IUCN 2019). For estimate the EOO and the Area of Occupancy (AOO), we used the geospatial conservation assessment tool GeoCAT, an open source (http:// geocat.kew.org/), browser-based tool used for performs rapid geospatial analysis to ease the process of Red Listing taxa (Bachman et al. 2011). This tool is currently being used to evaluate and compare the EOO and AOO of threatened species (IUCN 2019). To calculate the area of forest overlapping the altitudinal range of $N$. mixomaculatus inside natural reserves, we use a shapefile of forest cover provided by the Programa Nacional de Conservación de Bosques para la Mitigación del Cambio Climático (Bosques 2016). The forest extension was calculated from Minimum Bounding Geometry routine in Arc Tool Box (ESRI 2016).

For the tests of chytrid fungal infection we used a real-time polymerase chain reaction (PCR) assay on DNA material collected on skin swabs to quantify the level of Batrachochytrium dendrobatidis Longcore, Pessier \& D.K. Nichols (Bd) infection (Boyle et al. 2004). We extracted DNA from swabs using $40 \mathrm{ml}$ of PrepMan Ultra, and analyzed extracts with a QuantStudio 3 qPCR system (ThermoFisher Scientific) following the protocol of Boyle et al. (2004) and Hyatt et al. (2007). We analyzed each extract once. We calculated the number of zoospore equivalents $\mathrm{ZE}$ (i.e., the genomic equivalent for $\mathrm{Bd}$ zoospores) by comparing the qPCR results to a serial dilution of standards (gBlock synthetic standards, IDT DNA, Iowa, USA) and considered any sample with ZE $>1$ to be infected, or Bd-positive. We deposited the dataset of $\mathrm{Bd}$ prevalence and infection load at the online database https://amphibiandisease.org/.

\section{Results}

\section{Nymphargus mixomaculatus (Guayasamin, Lehr, Rodriguez \& Aguilar, 2006)}

Figure 1

New records. PERU - San Martín Department • Mariscal Caceres Province, Quintecocha; 06 $50.96^{\prime} \mathrm{S}, 077^{\circ}$ 42.65'W; 3,180 m alt.; 23.XI.2003; Pablo J. Venegas leg.; 3 ô, CORBIDI 04377-04379 • Mariscal Caceres Province, Los Cóndores Lagoon; 06 $51.55^{\prime} \mathrm{S}, 077^{\circ} 42.24^{\prime} \mathrm{W}$; 3,010 m alt.; 19.V.2012; Pablo J. Venegas leg.; 1 ô, CORBIDI 11041 - Amazonas Department • Bongará Province, Chisquilla; $05^{\circ} 53.42^{\prime} \mathrm{S}, 077^{\circ} 42.72^{\prime} \mathrm{W} ; 2,920 \mathrm{~m}$ alt.; 26.VI.2017; Pablo J. Venegas leg.; 1 ふै, CORBIDI 18905 - Utcubamba Province, Bosque Quemado; 05³6.32'S, 078¹4.82'W; 3,080 m alt.; 29.XI.2019; Pablo J. Venegas, Luis A. García-Ayachi, Juan C. Chávez-Arrivasplata, Axel Marchelie leg.; 3 ô, CORBIDI 21261-21263.

Identification. We identified the collected specimens from the diagnostic characters of $N$. mixomaculatus according to Guayasamin et al. (2006). The eight voucher specimens reported here are easily identified as $N$. mixomaculatus by having the following diagnostic traits: (1) humeral spine absent; (2) no webbing between finger I, II, and III; (3) finger I shorter than II; (4) vomerine teeth absent; (5) ulnar and tarsal tubercles or folds absent; (6) absence of white pigment in the visceral or hepatic peritonea; (7) in life, pale green dorsum with scattered minute white and black spots (black spots absent on limbs); in preservative, dorsum lavender with minute white and dark purple spots; and (8) snout-vent length in males between 22.8 and $25.0 \mathrm{~mm}$.

In Peru, only N. erminae Torres-Gastello, SuárezSegovia \& Cisneros-Heredia, 2007 from central and northern Peru (Torres-Gastelo et al. 2007; Twomey et al. 2014) and N. truebae Duellman, 1976 from southern Peru (Duellman 1976) can be confused with N. mixomaculatus because these species also have dark dorsal spots. However, we easily identified our specimens as $N$. mixomaculatus because they lack black spots on limbs (these are numerous in N. truebae (see Duellman 1976) and scattered and blue spots in $N$. erminae) and 


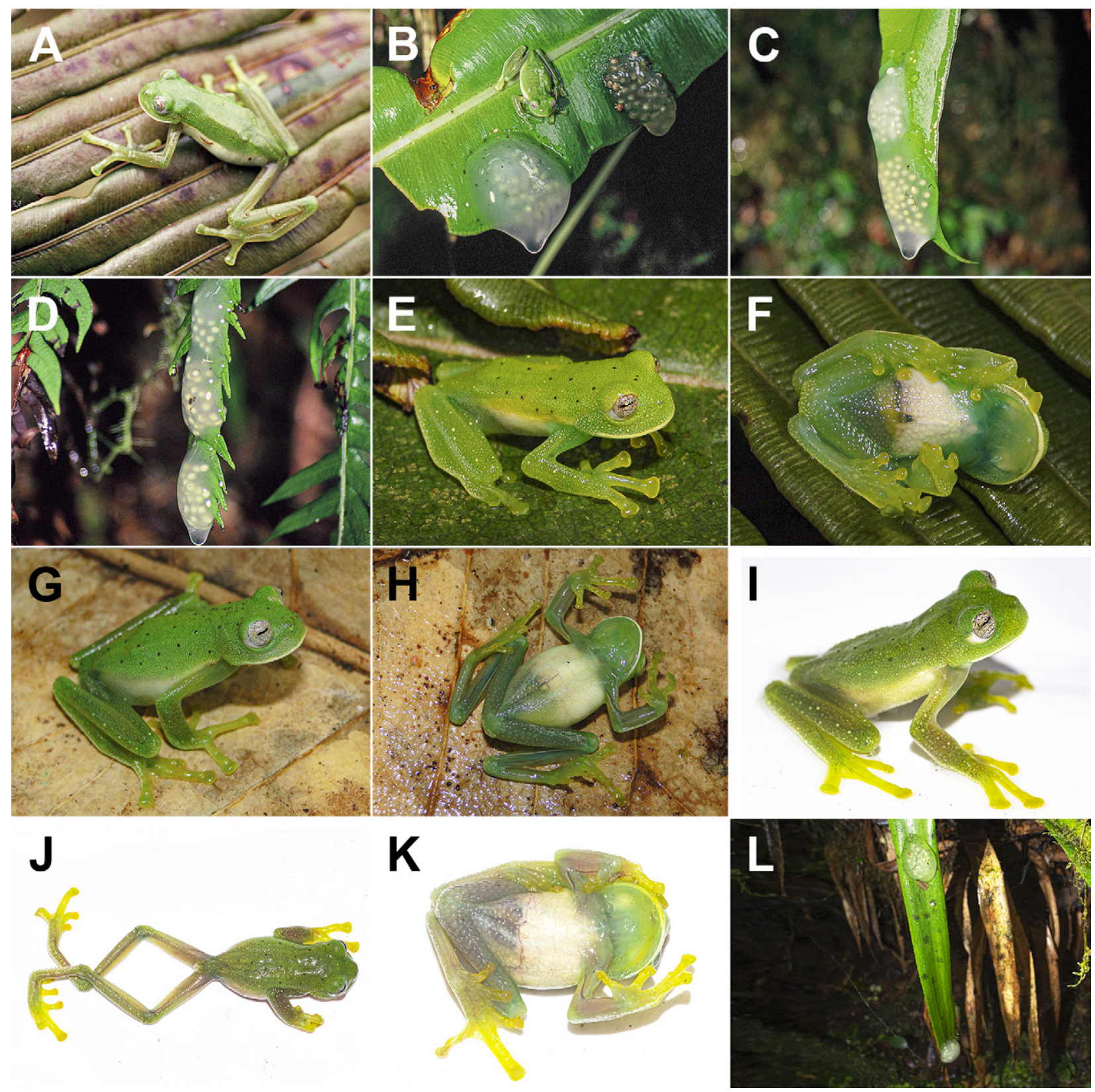

Figure 1. Males of Nymphargus mixomaculatus and their eggs clutches collected in the four new localities. A, B. Dorsolateral view of male CORBIDI 4377 from Quitecocha lagoon by day and watching its eggs by night, respectively. C, D. Eggs clutches of N. mixomaculatus at Quintecocha. E-F. Dorsolateral and ventral view of male CORBIDI 11041 from Los Condores lagoon. G-H. Dorsolateral and ventral view of male CORBIDI 18905 from Chisquilla. I-K. Dorsolateral, dorsal, and ventral view of male CORBIDI 21261 from Bosque Quemado. L. Two eggs clutches of N. mixomaculatus on a bromelia leaf at Bosque Quemado.

by the presence of scattered white spots on the dorsum and limbs (there are abundant white spots on dorsum and limbs in N. erminae (see Torres-Gastelo et al. 2007: fig. 1).

Remarks. Along a creek at Quintecocha Lagoon after a prolonged rain, we collected three males at $22 \mathrm{~h} 00$. They were calling from the same leaves of their egg clutches (Fig. 1A, B). We counted 16 males along less than $10 \mathrm{~m}$ of stream, all calling on leaves of various species of fern. We observed several eggs clutches at heights from 1 to $3 \mathrm{~m}$ above the ground, including more than one clutch on the same leaf (Fig. 1C, D). This creek is the drainage of the Quintecocha Lagoon (Fig. 2A), which drains into Los Cóndores Lagoon. The creek crosses an elongate patch of elfin forest (Fig. 2B), which turns into dense montane forest with high canopy around the Los Cóndores Lagoon. We found Pristimantis corrugatus Duellman, Lehr \& Venegas, 2006 and Telmatobius atahualpai Wiens, 1993 with N. mixomaculatus along the same reach of the creek. The new records of $N$. mixomaculatus are from 3,180 $\mathrm{m}$ a.s.1. and extend the altitudinal distribution of this species upwards by $430 \mathrm{~m}$ from $2,750 \mathrm{~m}$, the previously known maximum elevation for the species at the type locality in the Cordillera del Carpish in central Peru (Guayasamin et al. 2006).

At Los Cóndores Lagoon, we collected one male (Fig. $1 \mathrm{E}, \mathrm{F})$ at $21 \mathrm{~h} 00$. It was perched on a leaf at $2 \mathrm{~m}$ above the ground and adjacent to a narrow creek that crosses a primary montane forest near a big lagoon (Fig. 2C). 

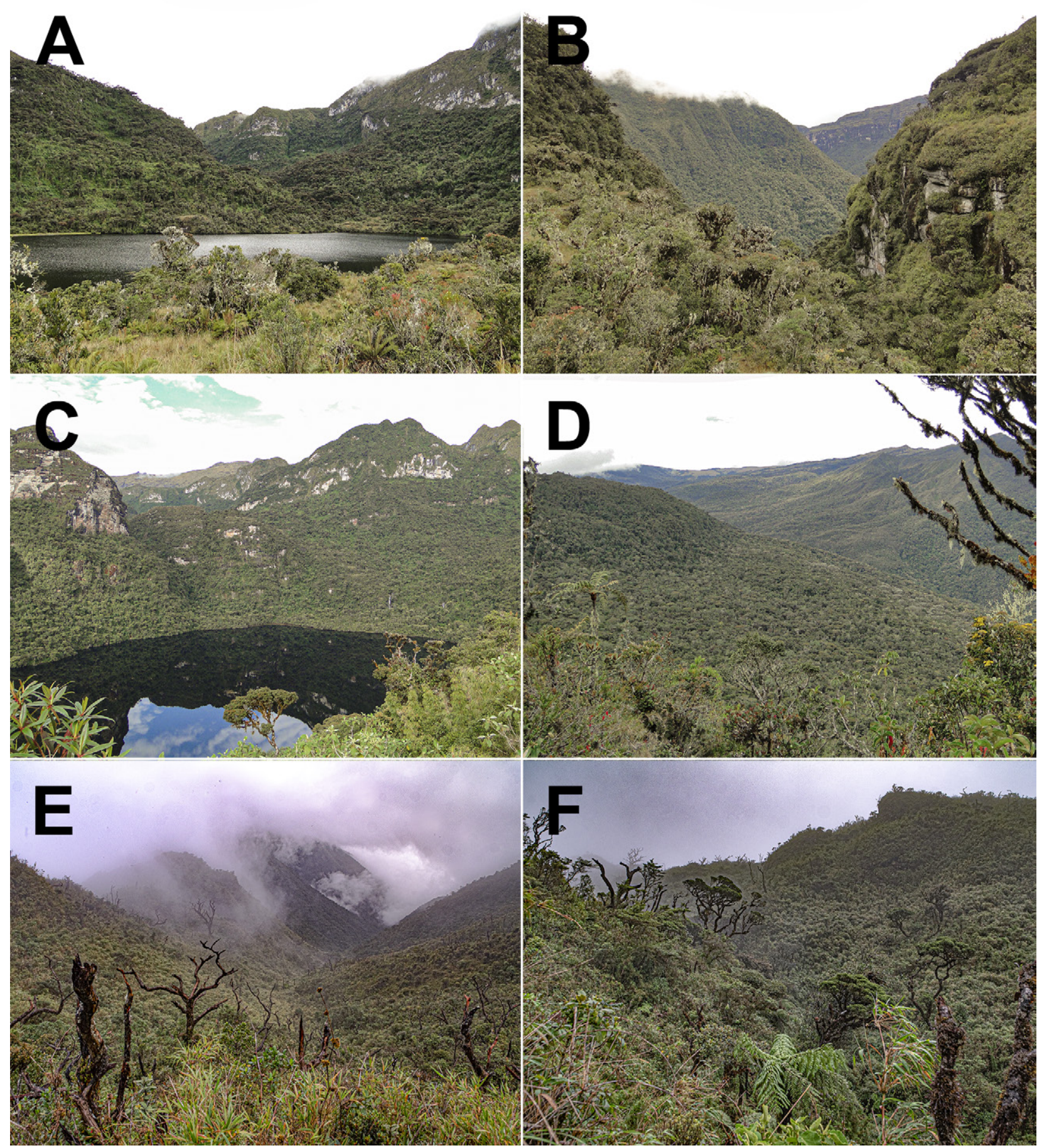

Figure 2. General landscape in each new locality. A. The ecotone between elfin forest and Paramo in the landscape of Quintecocha lagoon (taken May 2012). B. The canyon stream were the Nymphargus mixomaculatus were recorded in Quintecocha lagoon (May 2012). C. The steep slope where was recorded an individual of . mixomaculatus in Los Condores Lagoon (May 2012). D. The montane forest of Chisquilla in the buffer zone of Bosque de Proteccion Altomayo (June 2017). E. The ecotone between paramo and montane forest in Bosque Quemado. F. Steep slopes where inhabit N. mixomaculatus in Bosque Quemado (taken November 2019). Photographs A-D by P.J. Venegas and $\mathrm{E}$ and $\mathrm{F}$ by $\mathrm{A}$. Marchelie.

Sympatric anurans included Pristimantis corrugatus, Pristimantis wagteri Venegas, 2007, and Rhinella arborescandens Duellman \& Schulte, 1992. At this locality, individuals of $N$. mixomaculatus were found in a steep, forested area with a canopy of 4-7 m high (Fig. 2C). Several narrow creeks than drain into Los Cóndores Lagoon descend from higher lagoons located at the summit, such as Quintecocha and El Plomo lagoons.
At Chisquilla along a narrow creek near the border of an area cleared for cattle ranching, at $19 \mathrm{~h} 45$ we found a single male individual calling (Fig. $1 \mathrm{G}, \mathrm{H}$ ) perched on a leaf at $1 \mathrm{~m}$ above ground. The area is a steep slope covered by montane forest with small, scattered clearings for cattle close to a summit covered by Stipa L. spp., grasses, ground-living bromeliads, and patches of elfin forest (Fig. 2D). The canopy of the montane forest reached 
approximately from 4 to $6 \mathrm{~m}$ high. The single sympatric frog we found was $P$. corrugatus.

At Bosque Quemado along narrow creeks in very steep slopes, we heard several additional males calling after rains at $20 \mathrm{~h} 00$. One male (Fig. 1I, K) was calling near its egg clutch on the same leaf of a bromeliad at 1 $\mathrm{m}$ above the water (Fig. 1L). Two other males were calling on leaves at $2 \mathrm{~m}$ above ground. We also found two more egg clutches without a nearby male. Other anurans found in the same creeks were $P$. corrugatus and $R$. arborescandens. The general habitat is a paramo-covered mountaintop at an elevation of 3100-3200 m a.s.l., and several creeks drain down forest slopes (Fig. 2E). Nymphargus mixomaculatus inhabits the narrow creeks at the tree line where vegetation is dense (Fig. 2F). The record from Bosque Quemado extends the distribution range of $N$. mixomaculatus by approximately $513 \mathrm{~km}$ in a straight line north-northwest (Fig. 3) from the type locality (Guayasamin et al. 2006).

\section{Discussion}

Nymphargus mixomaculatus inhabits at elevations from 2,650 to $3,180 \mathrm{~m}$ a.s.1. along the eastern slopes of the northern portion of the Cordillera Central, from Huánuco to Amazonas departments, Peru (Guayasamin et al. 2006; new data herein). This species is known from a narrow altitudinal range $(530 \mathrm{~m})$, which is similar to other glassfrogs (Guayasamin et al. 2020). However, $N$. mixamaculatus is one of few glassfrog species reaching elevations above 3,000 m (Duellman 1976; Duellman and Schulte 1993; Twomey et al. 2014; Guayasamin et al. 2020). Our observations show that the reproductive activity, based on abundance of egg clutches and males calling, coincide with the beginning of the rainy season, at the end of November.

Nymphargus mixomaculatus is listed by IUCN as Critically Endangered due to its occurrence in one threat-defined location, with a known EOO of less than $10 \mathrm{~km}^{2}$, and continuing decline in the area and quality of its habitat in the Cordillera de Carpish (IUCN SSC Amphibian Specialist Group 2018). However, beginning 2020, the regional government of Huánuco Department created the Área de Conservación Regional Bosque Montano de Carpish, a new natural reserve that protects 50,559.21 ha (MINAM 2020) of montane forest between 830 and 3,913 $\mathrm{m}$ in elevation. The presence of $N$. mixomaculatus inside this reserve is very likely because its southernmost border is only $2.9 \mathrm{~km}$ from the species' type locality. Furthermore, the four additional localities reported here for $N$. mixomaculatus are located within or in the boundary of protected natural areas. Habitat lost and fragmentation were observed at Chisquilla and Bosque Quemado. The anthropogenic disturbances in Chisquilla are represented only by some scattered clearings for cattle. However, Chisquilla is near the western boundary (buffer zone) of the Bosque de Protección Alto Mayo, a 182,000 ha area protected by the Peruvian government (SERNANP 2020). The Bosque Quemado (Burnt Forest in English) is currently undergoing regeneration because in 2009, the same year the protected area was created, illegal land dealers started a fire that burned the paramo and the adjacent montane forest. This protected area lies within the southern section of Santuario Nacional Cordillera de Colán, a 39,237.61 ha area protected by the Peruvian government (SERNANP 2020). Since 2012, the area of Quintecocha and Los Cóndores Lagoon is part of the Área de Conservación Privada Los Chilchos, a private protected area of 46,000 ha (SERNANP 2020) owned by the rural community of Leimebamba, and both areas have forest in good condition without signs of fragmentation or degradation since our first visit in 2003 .

Given habitat lost and modification are believed to be the most important threats for Peruvian amphibians (Catenazzi and von May 2014), including glassfrogs (Guayasamin et al. 2020), habitat preservation is crucial to protect amphibian species facing human-induced threats (von May et al. 2009; Guayasamin et al. 2020). We find 17 natural reserves of different types within or near of the polygon of distribution (Fig. 3): national sanctuaries, protected forest, reserved zones, and national parks which are protected by the Peruvian government; private conservation areas, protected by rural communities or private land owners; and regional conservation areas, protected by regional government. In fact, altogether these areas protect 156,227 ha of montane forest, which overlaps with or is adjacent to the geographic and altitudinal range of $N$. mixomaculatus (Table 1). The presence of this endemic species in private or regional conservation areas highlights the importance of these areas for the conservation of threatened anurans in Peru.

We surveyed the $\mathrm{Bd}$ in anurans at Bosque Quemado and did not detect infection in the three sampled specimens of N. mixomaculatus (CORBIDI 21261-21263). However, $\mathrm{Bd}$ prevalence among syntopic frogs was $10.2 \%$ (Bayes $95 \%$ credible interval with Jeffrey's priors: 3.7-18.7\%). Among six infected frogs, only one had ZE > 10,000, a threshold known to be associated with elevated mortality (Kinney et al. 2011; Catenazzi et al. 2017). A higher level of infection, $\mathrm{ZE}=12,904$, was recorded in a specimen of Gastrotheca abdita Duellman, 1987 (CORBIDI 21281). In the same month, less than approximately $7 \mathrm{~km}$ southwest of Bosque Quemado, nine other individuals of glass frogs (six Centrolene lemniscatum Duellman \& Schulte, 1993 and three Nymphargus sp.) were swabbed at lower elevations (2184-2712 m a.s.1.), and only one individual of C. lemniscatum (CORBIDI 21190 ) tested positive, with $\mathrm{ZE}=1.302$, which is nonlethal at that level (Kinney et al. 2011). Bd prevalence and infection loads were overall low in Bosque Quemado and adjacent areas compared to other frog assemblages in the high Andes (Catenazzi and von May 2014).

The presence of an invasive species, Rainbow Trout, Oncorhynchus mykiss (Walbaum, 1792), a species known to negatively affect Neotropical amphibian 


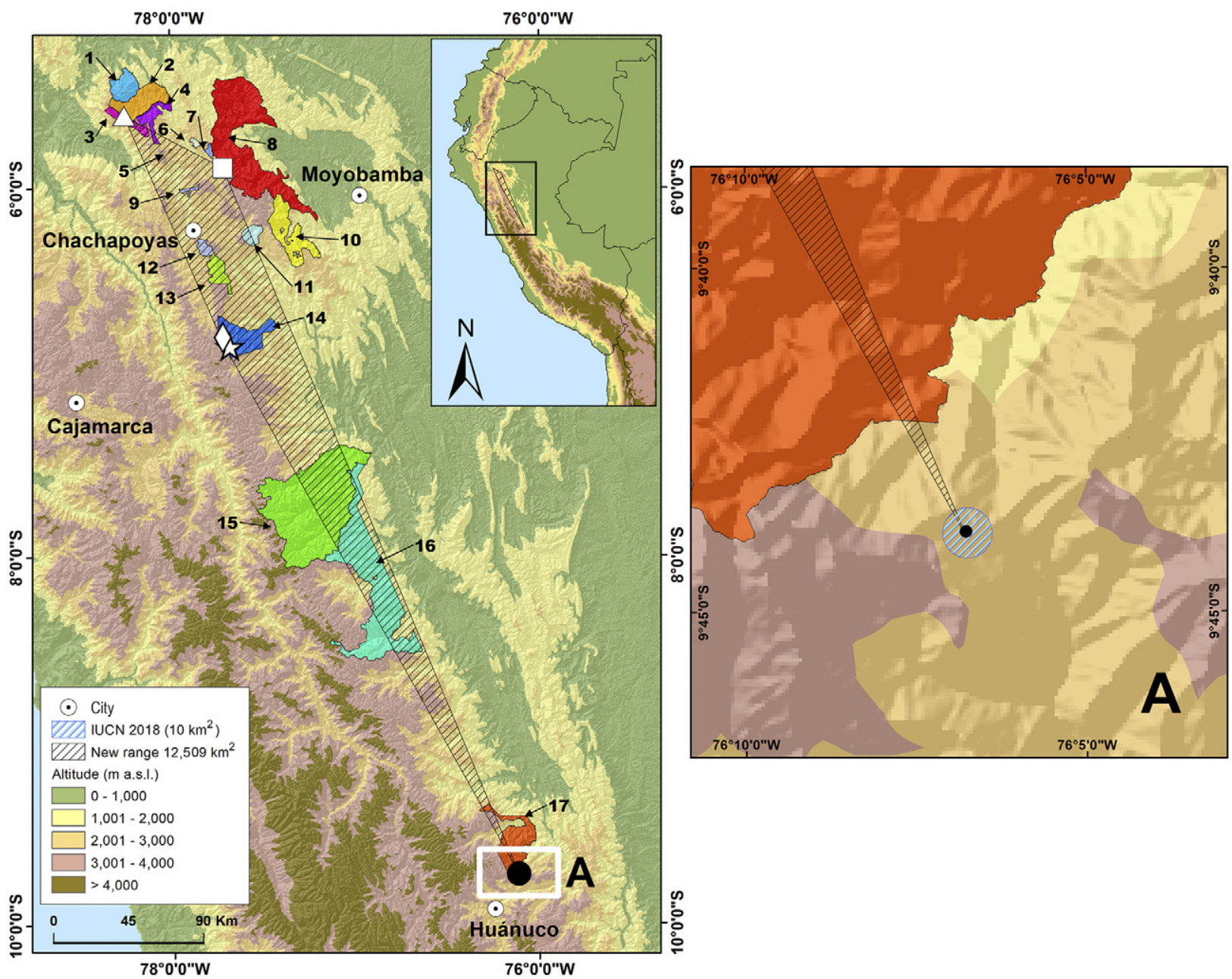

Figure 3. The geographic range of Nymphargus mixomaculatus showing the natural reserves adjacent or overlapped on its range. Black circle = type locality, diamond $=$ Quintecocha lagoon, star $=$ Los Condores lagoon, square $=$ Chisquilla, and triangle $=$ Bosque Quemado. 1 = Reserva Comunal Chayu Nain, 2 = Santuario Nacional Cordillera de Colán, 3 = ACP Copallín, 4 = ACP Monte Puyo (Bosque de Nubes), $5=$ ACP Arroyo Negro, 6 = ACP Copal Cuilungo, 7 = ACP Hierba Buena-Allpayacu, $8=$ Bosque de Protección Alto Mayo, $9=$ ACP Comunal San Pablo-Catarata Gocta, 10 = ACR Vista Alegre-Omia, $11=$ ACP Bosque de Palmeras de la Comunidad Campesina Taulia Molinopampa, $12=$ ACP Tilacancha, 13 = ACP Llamapampa-La Jalca, 14 = ACP Los Chilchos, $15=$ Parque Nacional del Río Abiseo, $16=$ ACR Bosques de Shunté y Mishollo, and 17 = ACR Bosque Montano de Carpish.

Table 1. The various types of natural reserves that protect montane forest adjacent or within the range (polygon) of Nymphargus mixomaculatus ACP = Área de Conservación Privada (private natural reserve), ACR = Área de Conservación Regional (regional natural reserve).

\begin{tabular}{|c|c|c|}
\hline Natural reserves & Total area (ha) & $\begin{array}{c}\text { Area of montane forest (ha) } \\
\text { between } 2,650 \text { and } 3,180 \mathrm{~m} \text { alt. }\end{array}$ \\
\hline ACP Arroyo Negro & 156.42 & 92.22 \\
\hline ACP Bosque de Palmeras de la Comunidad Campesina Taulia Molinopampa & $10,920.84$ & $3,676.01$ \\
\hline ACP Comunal San Pablo - Catarata Gocta & $2,603.57$ & 365.84 \\
\hline ACP Copal Cuilungo & $2,573.07$ & 203.91 \\
\hline ACP Copallín & $11,558.74$ & $5,816.33$ \\
\hline ACP Hierba Buena - Allpayacu & $2,282.12$ & $1,562.81$ \\
\hline ACP Llamapampa - La Jalca & $17,502.93$ & $8,244.29$ \\
\hline ACP Los Chilchos & $46,000.01$ & $11,251.10$ \\
\hline ACP Monte Puyo (Bosque de Nubes) & $16,157.57$ & $3,885.06$ \\
\hline ACP Tilacancha & $6,800.48$ & 366.17 \\
\hline ACR Bosque Montano de Carpish & $50,559.21$ & $7,731.00$ \\
\hline ACR Bosques de Shunté y Mishollo & $191,405.53$ & $31,696.11$ \\
\hline ACR Vista Alegre-0mia & $48,944.51$ & $14,372.98$ \\
\hline Bosque de Protección Alto Mayo & $182,000.00$ & $19,301.98$ \\
\hline Parque Nacional del Río Abiseo & $274,520.00$ & $42,713.70$ \\
\hline Reserva Comunal Chayu Nain & $23,597.76$ & $1,348.40$ \\
\hline Santuario Nacional Cordillera de Colán & $39,237.61$ & $3,598.90$ \\
\hline
\end{tabular}


populations (Martín-Torrijos et al. 2016), was observed only in Los Cóndores Lagoon. Here several narrow streams, which are habitat for N. mixomaculatus, are on a very steep slope and descends $150 \mathrm{~m}$ to the lagoon. In the other localities reported here, the glassfrogs were observed also in narrow streams that descended on very steep slopes with presence of waterfalls. We considered that the steep slopes with waterfalls are an obstacle for the trout and this invasive species is not a threat to $N$. mixomaculatus.

With the inclusion of our new records, we estimate the EOO and AOO of N. mixomaculatus to be $12,510 \mathrm{~km}^{2}$ and $20 \mathrm{~km}^{2}$, respectively. As found by our field observations, this glass frog inhabits large areas with primary forest, some of these near or within protected areas. Furthermore, this species can tolerate disturbance, such as low-level fragmentation (e.g., Chisquilla) and can recolonize habitats after fires (e.g., Bosque Quemado). We did not find current evidence for considering trout and $\mathrm{Bd}$ as important threats to N. mixomaculatus, both of which have well-known impacts on Neotropical amphibians (Skerratt et al. 2007; Catenazzi and von May 2014; Martín-Torrijos et al. 2016).

Thus, due to the lack of evidence about continuing decline or extreme fluctuations in area or quality of habitat. We recommend the status of Nymphargus mixomaculatus to be reclassified from Critically Endangered to Vulnerable following the criterion D2 (IUCN 2019), as this species has an AOO of $20 \mathrm{~km}^{2}$ and $\leq 5$ locations.

\section{Acknowledgements}

We are especially grateful with the Servicio Nacional de Áreas Naturales Protegidas por el Estado, especially with the professional personnel of the Santuario Nacional Cordillera de Colán: Christian Olivera, Jhonny D. Ramos, Gerlys Fernandez, and Abner García for logistic support. This research was made possible with the support of the Critical Ecosystem Partnership Fund (project number CEPF-109938) through the Fondo de Promoción de las Áreas Naturales Protegidas del Perú (PROFONANPE). We also thank the Mohamed bin Zayed Species Conservation Fund (project number 0925417), Yunkawasi, and the Global Genome Initiative for their support. Our field work would not have been possible without the logistic support of the following people: Marco Salas of Ucumari, Fanny M. Cornejo of Yunkawasi, Odile Sanchez and Claudia Zarate of PROFONANPE. We thank to A. Marchelie for his photographs of Bosque Quemado. We also thank with Santiago Bullard, Axel Marchelie, Juan C. Chávez, and Jesús Ormeño for their company and field assistance. Finally, we are indebted with Alessandro Catenazzi and Fernando Angulo for the early review of the manuscript, and Juan M. Guayasamin for improved this article with his comments in the review process.

\section{Authors' Contributions}

PJV conceived the paper, wrote and revised the manuscript, collected data, and identified specimens; LAGA collected specimens, revised the manuscript, prepared the map, and prepared figures and table. Both authors approved the final version of the manuscript.

\section{References}

AmphibiaWeb (2020) AmphibiaWeb. University of California, Berkeley, USA https://amphibiaweb.org. Accessed on: 2020-12-13.

Bachman S, Moat J, Hill A, de la Torre J, Scott B (2011) Supporting Red List threat assessments with GeoCAT: geospatial conservation assessment tool. ZooKeys 150: 117-126. https://oi.org/ 10.3897/zookeys.150.2109

Bosques (2016) Mapa nacional de covertura vegetal. Ministerio del Ambiente, Lima, Peru. http://www.bosques.gob.pe. Accessed on: 2020-06-22.

Boyle, DG, Boyle, DB, Olsen, V, Morgan, JAT, Hyatt, AD (2004) Rapid quantitative detection of chytridiomycosis (Batrachochytrium dendrobatidis) in amphibian samples using real-time Taqman PCR assay. Diseases of aquatic organisms 60: 141-148. https://doi.org/10.3354/dao060141

Catenazzi A, von May R (2014) Conservation status of amphibians in Peru. Herpetological Monographs 28 (1): 1-23. https://doi.org/ 10.1655/herpmonographs-d-13-00003

Catenazzi A, Swei, A, Finkle, J, Foreyt, E, Wyman, L, Vredenburg, VT (2017) Epizootic to enzootic transition of a fungal disease in tropical Andean frogs: are surviving species still susceptible? PLoS ONE 12: e0186478. https://doi.org/10.1371/journal.pone.0186478

Duellman WE (1976) Centrolenid frogs from Perú. Occasional papers of the Museum of Natural History 52: 1-11.

Duellman WE, Schulte R (1993) New species of centrolenid frogs from northern Peru. Occasional papers of the Museum of Natural History 155: 1-33.

ESRI (2016) ArcGIS Desktop: Release 10.5. Environmental Systems Research Institute.

Guayasamin JM, Lehr E, Rodríguez D, Aguilar C (2006) A new species of glass frog (Centrolenidae: Cochranella ocellata group) from central Peru. Herpetologica 62 (2): 163-172. https://doi.org/ 10.1655/05-21.1

Guayasamin, JM, Castroviejo-Fisher S, Trueb L, Ayarzagüena J, Rada M, Vilà C (2009) Phylogenetic systematics of glassfrogs (Amphibia: Centrolenidae) and their sister taxon Allophryne ruthveni. Zootaxa 2100: 1-97. https://doi.org/10.11646/zootaxa.2100.1.1

Guayasamin JM, Cisneros-Heredia DF, McDiarmid RW, Peña P, Hutter CR (2020) Glassfrogs of Ecuador: diversity, evolution, and conservation. Diversity 12: 222 https://oi.org/10.3390/d12060222

Hyatt, DG, Boyle, AD, Olsen, V, Boyle, DB, Berger, L, Obendorf, D, Phillott, R (2007) Diagnostic assays and sampling protocols for the detection of Batrachochytrium dendrobatidis. Diseases of Aquatic Organisms 73: 175-192. https://doi.org/10.3354/ dao073175

IUCN (2019) Guidelines for Using the IUCN Red List categories and criteria: Version 14. International Union for Conservation of Nature and Natural Resources, Gland, Switzerland, 113 pp. https://www. iucnredlist.org/resources/redlistguidelines. Accessed on: 202006-18.

IUCN SSC Amphibian Specialist Group (2018) Nymphargus mixomaculatus. The IUCN Red List of threatened species 2018: e.T135886A89218196. International Union for Conservation of Nature and Natural Resources. https://doi.org/10.2305/iucn.uk. 2018-1.rlts.t135886a89218196.en Accessed on: 2020-06-22.

Kinney, VC, Heemeyer, JL, Pessier, AP, Lannoo, MJ (2011) Seasonal pattern of Batrachochytrium dendrobatidis infection and mortality in Lithobates areolatus: affirmation of Vredenburg's "10,000 
Zoospore Rule". PLoS ONE 6: e16708. https://doi.org/10.1371/ journal.pone.0016708

Martin-Torrijos L, Sandoval-Sierra J, Muñoz J, Diéguez-Uribeondo J, Bosch J, Guayasamin J (2016) Rainbow Trout (Oncorhynchus mykiss) threaten Andean amphibians. Neotropical Biodiversity 2: 26-36. https://doi.org/10.1080/23766808.2016.1151133

MINAM (Ministerio Nacional del Ambiente) (2020) D.S. N 14-2019-MINAM: Decreto Supremo que establece el Área de Conservación Regional Bosque Montano de Carpish, Lima, Peru, $28 \mathrm{pp}$.

SERNANP (Servicio Nacional de Áreas Naturales Protegidas por el Estado) (2020) Sistema Nacional de Áreas Naturales Protegidas por el Estado._Estado Peruano, Lima, Perú. https://www.sernanp. gob.pe. Accessed on: 2020-06-22.

Skerratt LF, Berger L, Speare R, Cashins S, McDonald KR, Phillott
AD, Hines HB, Kenyon N. (2007) Spread of chytridiomycosis has caused the rapid global decline and extinction of frogs. Ecohealth 4: 125-34. https://doi.org/10.1007/s10393-007-0093-5

Torres-Gastello CP, Suárez-Segovia J, Cisneros-Heredia DF (2007) Cochranella erminea, a new species of Centrolenidae (Amphibia: Anura: Athesphatanura) from Amazonian Peru. Journal of the National Museum 176: 1-12.

Twomey E, Delia J, Castroviejo-Fisher S (2014) A review of northern Peruvian glassfrogs (Centrolenidae), with the description of four new remarkable species. Zootaxa 3851 (1): 1-87. https://doi. org/10.11646/zootaxa.3851.1.1

von May R, Siu-Ting K, Jacobs JM, Medina-Mueller M, Gagliardi G, Rodriguez LO, Donnelly MA (2009) Species diversity and conservation status of amphibians in Madre de Dios, southern Peru. Herpetological Conservation Biology 4: 14-29. 